was an important and authoritative counter-statement to that of Bourbakist extremism which was being propounded in other places.

Newman was already 62 when he gave that address, but he was a man who remained young in spirit, and who had continued to bring a refreshing originality to English mathematics. Before the war, in a Cambridge dominated by the great school of analysis associated with Hardy and Littlewood, he struck out on his own into combinatorial topology-a period which culminated, in 1939, in the publication of Topology of plane sets of points. Dr Frank Smithies, reviewing this in the Gazette (December 1939), asserted that "it is an excellent specimen of the English variety of textbook at its best", and expressed the hope that "as one result of its appearance, more attention will be paid to the subject of topology in the mathematics departments of British universities". But Newman's move to Bletchley Park during the war, in company with many other distinguished mathematicians, led to an involvement with electronic machines for cryptanalysis; and in consequence, the early research in digital computing became a major interest when in 1945 he moved to the University of Manchester as Fielden Professor. (An interesting account of these developments, and of Newman's part in them, is given by B. Randell, "The history of digital computers", in the Bulletin of the IMA for November/December 1976.)

Newman's connection with the Mathematical Association began in the 1950s, when he accepted the invitation of the Teaching Committee to be chairman of its sub-committee on the teaching of algebra in sixth forms. It was an important choice, for he brought to the discussions a clarity of purpose which few could have matched. His personal influence is seen most strongly in the sections of the report on polynomials and on axioms, but it was his hand which guided the whole enterprise.

But for those who worked with him, the predominant memory will not be of his formidable intellect or his capacity for organisation, but of his warm friendship, his kindly encouragement, and his delightful sense of fun. We are privileged to have enjoyed our share of these qualities.

DOUGLAS QUADLING

Cambridge Institute of Education, Shaftesbury Road, Cambridge CB2 $2 B X$

\title{
Allan W. Riley
}

Allan W. Riley who died on the 23rd November 1983, aged 82, was a Lancastrian. He graduated with BSc Honours in Mathematics from Manchester University. He taught in various schools before his appointment as Head of the Edward Shelley School in Walsall. From there, on the 1st October 1940, he was appointed Inspector of Schools for the County Borough of Wolverhampton when his predecessor in that post became the Director of Education. From that date up to the time of his retirement on the 31 st August 1967 no-one exercised greater influence on the pattern and 
content of schooling in the Borough of Wolverhampton than did Allan Riley. Inspectors were thin on the ground in those early days and their personal influence was inevitably considerable.

As an educationist he was a front runner and those of us who followed had much to thank him for. He gave Wolverhampton 'acres and acres' of start in many 'areas'. In discussing content and method in mathematics programmes for his primary teachers Allan was always aware of the difficulties teachers were called upon to tackle. It is probably true to say that his Primary Heads were his favourites-he had favourites among his favourites as everyone knew. Their own mathematical knowledge was often inadequate and their experience of practical applications of mathematics absurdly small. Yet some were astonishingly inventive and logical. Allan understood their needs and was always ready to organise help for them. He trained them mathematically so that the local authority was able to standardise and correlate, in numerical terms, a 'new factor' in selection procedures: "The head teacher's overall assessment".

In the words of, until recently, a Director of Education of Wolverhampton: "By 1954 AWR was a power in the land". The Hadow reorganisation was past history, as were the more anecdotal accounts of wartime fire-watching. He was still running an astronomy/navigator's course for RAF cadets and he was already up to his eyes in the affairs of the Mathematical Association.

Allan's work with the Association began in the early 1930's at a time when he was Headmaster of a, then, 'Central' school at Stroud in Gloucestershire. It was about this time that a small sub-committee was set up and the results of its work was published in the Gazette (May 1934) under the title: "Mathematics in central schools"-a discussion which took place at the Annual Meeting, 5th January, 1934. Hitherto the influence of the Association had been exerted chiefly by the well-qualified mathematics teachers in the public schools through the reports they produced for the consideration of the members of the Association. They had played a remarkable part in the changes in school mathematics over the previous 50 years and which were now gathering speed. Interest was growing, too, in the ways in which fundamental mathematical ideas develop in the minds of young children.

Allan was elected to the Council of the Association in 1935. He did splendid work with the committees reporting on primary school mathematics teaching. The Association widened the scope of its influence and Allan was elected to represent the new perspective. Teaching Committee appointed a small sub-committee to consider and to report on the teaching of mathematics to children up to eleven years of age and Allan was appointed to serve on it. He brought to discussion his perceptive experience as a mathematics teacher and as an adviser under the Wolverhampton LEA. His enthusiasm for new approaches for giving young children basic mathematical insights into the objects and events around them led to the 
realisation of a body of principles which would inevitably improve mathematics teaching. He loved his trips to London on Association business and his contacts with those who shared his interest in mathematics teaching.

Then, alas!, came World War II and the committee could not meet. It was not until 1946 that the remnants of that committee could meet again. It was Allan who convinced its members that the previous 'report' should be scrapped, that their work must begin again-at the preliminary stage of experimental play with materials which would illustrate the existence and behaviour of numbers. The design of such material was remarkable and delighted Allan by its power to demonstrate the structure of the number system and the nature of the basic operations. The fundamental tenet on which the principles of the work was based was 'the absolute necessity for children's own experiments and constructions' whatever the kind of materials actually provided. Allan did not hesitate to support, and embody in the final Report, the almost emotional appeal to teachers to include such activity in connection with all the relations and operations which they introduced to young children.

The report on the teaching of mathematics in primary schools was finally published in 1955. Allan was very proud of the achievement as he had every right to be. He chaired the sub-committee from 1950-4 and probably wrote most of it himself: his heart was in it and indeed his heart was mathematics. The report conveyed the urgent message of the need for immediate action. It was Allan who secured the Association's approval to send two copies to each LEA in England, one for the Director of Education and one for his mathematics adviser, together with an offer to send a speaker to each area to explain the report and to ask for support and the means to put into effect its recommendations. The report became a best-seller and primary school mathematics was revolutionised in large measure through the unique contribution that Allan brought to the campaign. His work on the Teaching Committee culminated in a run of 9 years' service, 1957-1966, as its chairman. During his term of office the following reports were published:

Report on the teaching of algebra in sixth forms: 1957

Mathematics in secondary modern schools: 1959

Books and periodicals in the library of the mathematical association: 1962

The teaching of analysis in sixth forms: 1963

Applications of elementary mathematics: 1964

$A$ second report on the teaching of arithmetic in schools: 1964

A second report on the teaching of mechanics in schools: 1965

In all his work is felt his very great influence on the widening of the primary school mathematics curriculum to include much on spatial relationships and pattern.

He was elected a Vice-President of the Association in April 1972.

Allan Riley was a very likeable person. His keen, rather dry, sense of humour will be recalled by many on those occasions when he would speak either personally or in a meeting with a straight face but a twinkle in his 
eye! In him the Association has lost a sterling member, a good mathematician and a splendid teacher.

On fronts other than mathematics and teaching Allan Riley was equally involved. He was a keen musician and played the piano well. Whilst in the service of the Wolverhampton LEA he laid the foundations of the Wolverhampton Music Festivals. He invited the Birmingham Symphony Orchestra every year: special performances were given to schools in the afternoons to be followed by public performances in the evenings.

It was he who was responsible for the following appointments: the man, initially a part-timer, who later created the Audio-Visual Centre in Wolverhampton and the man who later developed the Remedial Teaching Service; it was Allan himself, after retirement in 1967 from full-time service, who laid the early foundations of the Wolverhampton Teaching Centre: all significant markers each and every one.

On the personal side, Allan Riley was much involved in church affairs being an elder of the Congregational Church. He was an outdoor enthusiast who knew his way around the Lake District and the mountains of North Wales. Even more personally, he will always be remembered by the children, including the off-spring of Wolverhampton's above-mentioned former Director of Education, for his unfailing distribution of tins of toffees at Christmas-tide and by all and sundry for boxes of apples in October.

As a result of a serious illness in 1976, Allan Riley was unable to attend any further meetings of the Mathematical Association. He himself, in a letter to a former friend and colleague, writes of the "many memories of working together stretching back to 1939: happy memories!" History repeats itself: in that same letter, when talking of the current mathematics teaching scene, he reminds us that "the mathematical core-for-all was accepted in 1916!" and that "unqualified people purporting to teach mathematics" had its parallel some years ago in "the dilution of O-level for political reasons!" He could have responded with "I told you so!" Instead, Allan and his contemporaries demonstrated that the shortcomings could be made good only by the right kind of in-service training. The opportunity then was crippled by financial cuts. What, he asks, can anyone like himself do about it under the limitations of a long and enforced retirement?

It is an honour to have been asked to write an appreciation of this unusual man. His courage in the face of family difficulties and tragedy was amazing: he was an unfailing friend in any problem. He is survived by his widow and two sons.

Acknowledgement is made to the very great help received from his friends in the preparation of this obituary: particularly to Alan Denis Grayson, until recently a Director of Education for Wolverhampton; to Elizabeth Williams and Walter J. Langford, former Presidents of the Association, and to Graham Merlane, Honorary Treasurer of the Association.

'Ramsbury', 53 Elveley Drive, West Ella, Hull HU6 $7 R X$

RUTH K. TOBIAS 